\title{
Gender heterogeneity of bureaucrats in attitude to corruption: evidence from list experiment ${ }^{1}$
}

\author{
Polina Detkova ${ }^{2}$ \\ Andrey Tkachenko ${ }^{3}$ \\ Andrei Yakovlev ${ }^{4}$
}

October 1, 2020

\begin{abstract}
A high level of corruption usually constrains economic development in emerging countries. However, anti-corruption campaigns often fail because the relevant policies need to be implemented by existing corrupt governments. This article studies the extent of bureaucrats' heterogeneity in attitude to the problem of corruption. Due to the sensitivity of direct questions on corruption, we conduct the list experiment among public procurement officials in Russia. We show that female bureaucrats consider corruption to be an obstacle of public procurement development and male bureaucrats do not. This heterogeneity holds even at the high-level occupied positions.
\end{abstract}

Keywords: gender heterogeneity, corruption, public procurement, item count technique, list experiment, Russia

JEL classification: D73, H57

\footnotetext{
1 This work was supported by the Program for Basic Research of the National Research University Higher School of Economics in 2019. The authors are grateful to Alexander Kalgin and members of EACES-HSE workshop 'Topics in Political Economy of Development'. We are also grateful to all respondents who spent their time to participate in the survey. All mistakes remain our own.

2 National Research University Higher School of Economics \& California Institute of Technology,pdetkova@gmail.com

3 National Research University Higher School of Economics \& Bocconi University, tkachenko_av@hse.ru

${ }^{4}$ Institute for Industrial and Market Studies, National Research University Higher School of Economics, ayakovlev@hse.ru
} 


\section{Introduction}

Corruption is commonly recognized as a roadblock of development. It is especially relevant in countries with weak democracies: a low level of political accountability and lack of sufficient public pressure on the officials do not incentivize existing corrupt bureaucrats to implement anti-corruption campaigns properly. Thus, for the successful implementation of the anti-corruption campaigns under existing institutional environments, it is necessary to understand which groups of bureaucrats can potentially support anti-corruption policies.

This article studies the heterogeneity in attitude to the problem of corruption among bureaucrats. We conduct an online list experiment among 1251 bureaucrats, responsible for the procurement activity in public organizations in Russia in 2014-2016. As corruption is a sensitive issue for bureaucrats, the list experiment technique mitigates the estimation bias in their attitude to this problem.

Our analysis shows significant gender heterogeneity. Namely, female bureaucrats appear to be likely to consider corruption a significant public procurement development problem and male bureaucrats do not. To use this finding as a potential anti-corruption policy, we check whether the low tolerance to corruption of female bureaucrats is caused by their occupied position. If women only at low positions consider corruption as a problem, promoting female officials would hardly reduce corruption. Our experiment results show that female bureaucrats at high positions are not tolerant of the corruption issue as well.

Russia is a compelling case for two reasons. On the one hand, it is a developing country with a high level of corruption ${ }^{5}$ and a vast bureaucracy. ${ }^{6}$ On the other hand, Russia introduced e-governance and the transparency of public spending. ${ }^{7}$ The scope of the penetration of information technologies allows to control bureaucratic activity and creates technical preconditions to limit corruption, which are absent in many other developing countries.

5 In 2017, Transparency International placed Russia 135th among 180 countries on its Corruption Perceptions Index (Transparency International, 2018).

${ }^{6}$ According to Rosstat, at the end of 2017, government staff at all levels included about 2173 thousand officials (http://www.gks.ru/wps/wcm/connect/rosstat main/rosstat/en/main/).

7 In 2018, Russia joined the group of countries with very high levels of e-government development (https://publicadministration.un.org/egovkb/en-us/Reports/UN-E-GovernmentSurvey-2018). 
This article focuses on bureaucrats dealing with public procurement for several reasons. First, unlike other officials, these bureaucrats are directly involved in decisions regarding the allocation of public money, and their practical experience makes their assessments of corruption much more valuable. Second, the regulation of public procurement is highly unified in Russia, and therefore, the assessments of respondents from different branches of the public sector are comparable. Finally, the high level of transparency of public procurement information in Russia enables us to access many officials.

Our results are in line with a part of the previous contradictory literature that women are less prone to corrupt activities than men (Dollar et al., 2001; Swamy et al., 2001; Alatas et al., 2009; Esarey and Chirillo, 2013; Rivas, 2013). However, our experimental design and estimates are more accurate. Namely, we contribute to this literature in two ways. First, we detect gender heterogeneity in attitude to corruption of actual bureaucrats. In contrast, the previous perception-based studies of corruption usually employ either surveys of consumers of public services (citizens and firms) or laboratory experiments. In the latter case, participants, usually college/university students, only 'pretend' to be bureaucrats. Thus, we focus on the 'insiders' of the bureaucratic system, not on those who do not make actual bureaucratic decisions. Second, the list experiment technique enables us to estimate the correct opinion of the bureaucrats. Questions on corruption are sensitive for respondents due to the illegal character of this activity. Therefore, many scholars have used impersonal forms of questions, asking respondents about the experience dealing with corruption for an 'average firm in your sector/region' or an 'average person' (Hellman et al., 2003; Alhassan-Alolo, 2007; Becker et al., 2016). However, even for a question in an impersonal form, bureaucrats may still feel that their answers to it will be treated as reflections of their personal experience, so they may distort their responses. The list experiment approach enables us to estimate the proportion of individuals, who consider corruption as a problem for public procurement, without discovering any individual opinion. That, in turn, leads to non-biased results. The remainder of the article is organized as follows. Section 2 reviews the literature on corruption and gender-related heterogeneity in the perception of corruption. Section 3 describes the list experiment technique and the data. Section 4 provides the results, and Section 5 shows robustness check. Section 6 concludes. 


\section{Literature review}

\subsection{Studies of Corruption}

Most of the articles devoted to the analysis of corruption can be classified into four major groups: (i) studies that use survey-based measures of corruption, (ii) laboratory experiments on corruption, (iii) theoretical studies of corruption, (iv) studies that use micro-level statistics (procurement contracts data).

The first group consists of empirical studies based on various types of surveys of public service consumers. These studies can be classified by the type of survey:

- Population surveys: the World Values Survey (worldvaluessurvey.org), the European Values Survey (europeanvaluesstudy.eu), the Life in Transition Survey (Becker et al., 2016)

- Business surveys: the World Competitiveness Report (Ades and Di Tella, 1999), BEEPS (ebrd-beeps.com), the Enterprise Surveys of the World Bank (enterprisesurveys.org)

- Expert assessments: the Business International indices of Doing Business (Bosio et al., 2020), the International Country Risk Guide (Tanzi and Davoodi, 1998), the Corruption Perceptions Index of the Transparency International (transparency.org/research/cpi)

More examples can be provided for each of the three types of surveys. These studies enable researchers to measure the scale of corruption and to register significant heterogeneity among countries in this respect. The studies also provide a basis for a more detailed analysis of the factors influencing corruption perception. Specifically, two pioneering studies of the relationship between corruption and gender (Dollar et al., 2001; Swamy et al., 2001) use corruption indices based on surveys. These studies show that women are less tolerant of corruption than men and that greater female participation in politics is generally associated with lower corruption levels. Further empirical studies based on surveys or expert assessments reveal an inverse relationship between the scale of corruption and the level of economic development in different countries (Tanzi and Davoodi, 1998; Wei, 1999; Aidt, 2009; Bosio et al., 2020).

All the studies of the first group use empirical data that reflect the perception of corruption by public service consumers. However, these perceptions are insufficient for anticorruption policy-making since perceptions of bureaucrats, as decision-makers, may 
differ. However, measuring the perception of corruption by officials is complicated, as they may provide distorted assessments to avoid any suspicion of their involvement in corruption. Few articles focus on the corruption perceptions of officials. One of these studies was based on a direct survey of bureaucrats in Ghana (Alhassan-Alolo, 2007). This survey included questions about the differences between the potentially corrupt practices of female and male officials. The study did not reveal significant differences between female and male officials in their attitudes to corrupt practices. However, due to the sensitivity of the research topic, such an approach can lead to biased results and may underestimate the scale and perception of corruption. Vijayalakshmi (2008) finds no association between gender and attitudes towards corruption for the elected representatives in India, but this survey also used direct questions for estimating the attitude to corruption.

To our knowledge, the study of Brierley (2020) is the only one that proposes an estimation of corruption from the perspective of government officials by using an indirect survey technique. She uses a randomized-response survey method to reveal the opinions of public procurement officials in Ghana. She asks them whether their choices of suppliers depend on whether the firms are likely to finance the incumbent party' election campaign. However, she does not explore the potential heterogeneity of the results, particularly gender differences.

The second group of studies comprises laboratory experiments. In laboratory experiments, participants, who are usually college/university students, represent the authorities, business people or citizens. The participants' behaviour is used for exploring corrupt behaviour with a further approximation to the society. Although some studies suggest that this approximation is justified, other studies point out the limitation of the lab experiment approach for the development of real-life policy implications that arise from the complexity of real agents' behaviour (Armantier and Boly, 2008; Barr et al., 2009; Banerjee, 2016). Therefore, the results of laboratory experiments alone should not be considered sufficient grounds for conclusions about real-life bureaucrats.

The third group of studies on corruption uses an entirely distinctive approach theoretical models (Mookherjee and Png, 1995; Chand and Moene, 1997; Macrae, 1982; Lambert-Mogiliansky and Sonin, 2006; Menezes and Monteiro, 2006). These articles usually identify factors that have an impact on incentives for corrupt behaviour 
and help find measures capable of influencing those incentives. However, in most cases, these studies do not answer the question of why politicians or bureaucrats, being in 'bad equilibrium', would make efforts to reduce factors that generate corruption. Another peculiarity of these works is a large number of assumptions. These assumptions may oversimplify reality and limit the practical use of the findings.

The fourth group of studies on corruption includes empirical studies that have become possible in recent years due to increased transparency and open access to data on public expenditures and government program execution (Golden and Picci, 2005; Olken, 2006; Gorodnichenko and Sabirianova Peter, 2007; Ferraz and Finan, 2011). Due to the unified nature of the procedures and a large number of public procurement contracts, the studies based on public procurement data analysis are now among the most popular in this group (Chong et al., 2013; Mironov and Zhuravskaya, 2016; Andreyanov et al., 2017; Tkachenko et al., 2017; Auriol et al., 2016; Szucs, 2017; Dávid-Barrett and Fazekas, 2020). Their significant advantages are the detection of transactions containing potentially corrupt elements and detailed analyses of such transactions' characteristics. However, as the former two groups, these studies do not provide much information about how to motivate decision-makers to implement anti-corruption policies - if we are not talking about changing the political regime.

\subsection{Corruption and gender}

Despite the abundance of research on corruption, in our opinion, the existing literature does not sufficiently uncover to what extent officials differ in their attitude to corruption and what bureaucratic groups can contribute to breaking away from the existing 'bad equilibrium' or vicious circle. Based on the studies on how female participation in politics and bureaucracy is related to corruption levels, we hypothesize that female bureaucrats can become such a group. Experimental (Alatas et al., 2009; Frank et al., 2011; Rivas, 2013) and macrolevel (Torgler and Valev, 2010; Sung, 2012; Esarey and Chirillo, 2013; Stensöta et al., 2015; Hao et al., 2017) studies generally point out a distinction between men and women in their perception of corruption. ${ }^{8}$ Brollo and Troiano (2016) use RDD design to show that female mayors in Brazil are less likely to

\footnotetext{
${ }^{8}$ Various aspects of the relationship between gender and corruption are discussed by Stensöta and Wängnerud (2018).
} 
participate in corrupt activities than male mayors. Besides, a few studies suggest that female managers of firms are less likely to be involved in corrupt activities than male managers (Breen et al., 2017; Ponomariov and Kisunko, 2018). In addition, Gingerich et al. (2016) find discrepancy between men and women in their attitude to bribes using an indirect survey technique. They find that men are more likely than women to show willingness to bribe.

These studies also offer a few mechanisms that might cause the empirically observed negative relationship between female participation and corruption levels. The mechanisms can be broadly divided into two groups, as Torgler and Valev (2010) suggest. The first group attribute the distinction to personal characteristics, and the second group suggest that male and female officials have different opportunities for corrupt behaviour. Concerning the first category, it is generally suggested that women are more risk-averse than men. This implies that women are less likely to participate in risky corrupt activities, and therefore, overall, the corruption level should be lower when female participation in politics or bureaucracy is higher (Rivas, 2013; Esarey and Schwindt-Bayer, 2018; Jha and Sarangi, 2018). Additionally, for example, Dollar et al. (2001) rely on previous gender studies and suggest that women might be more honest than men. The second group of mechanisms consider the constraints women may face in society compared to men. For example, women may have to meet higher standards if they run for a political or a bureaucratic office. Whether this happens due to women's social roles or due to stereotypes, these standards can prevent women from participating in corrupt activities (Alatas et al., 2009; Esarey and Chirillo, 2013; Stensöta et al., 2015; Esarey and Schwindt-Bayer, 2018). It is also possible that women's potential male counterparts or colleagues might not trust them enough to interact in a corrupt way (Swamy et al., 2001).

However, several studies find that it is not necessarily the case that a higher share of female bureaucrats would lead to a decrease in corruption levels. For example, Alatas at el. (2009) propose that the corruption-gender relationship depends on the institutional environment. Their experimental analysis indicates that women may be less tolerant of corruption than men in Australia; but in India, Indonesia, and Singapore, the corruption perception does not depend on gender. Esarey and Schwindt-Bayer (2018) also find distinctions between different countries; they suggest that electoral accountability might 
be a prerequisite for the negative relationship between female participation in politics and legislatures. Jha and Sarangi (2018) provide evidence that it is only the share of women in parliament that may have an impact on corruption levels. Debski et al. (2018) find that accounting for cultural differences in cross-country analysis eliminates the association of corruption levels with female participation in parliament and labour force. Length of tenure in office is also found to affect the relationship between gender and corruption (Afridi et al., 2017).

Overall, the literature on gender studies suggests that, in some institutional contexts, female officials can become an anti-corruption force. This article gives insight into the attitude to corruption by female and male officials in the Russian institutional environment. Russia is characterized by high level of corruption (Schulze et al., 2016), related, in particular, with political elites' incentives (Sidorkin and Vorobyev, 2017; Szakonyi, 2018; Tkachenko and Esaulov, 2020), and there is substantial heterogeneity of bureaucrats in public procurement effectiveness (Best et al., 2017).

\section{Methodology and data}

\subsection{Methodology}

To examine bureaucrats' attitude to corruption, we conducted an experiment in the framework of a survey among Russian officials that are directly involved in public procurement activity. This field was chosen for the analysis because public procurement procedures became unified in Russia after the last decade's reforms and due to the widespread use of information technologies. The same procedures are applied by various types of organizations in various branches of the public sector and therefore provide broad opportunities for comparisons.

The survey consists of questions regarding different aspects of public procurement process at all stages: problems in procurement practice, rigidity and necessity of regulation, public procurement costs (see Questionnaire in Online Appendix). All these aspects are well recognized in procurement literature and practice (Bosio et al., 2020). There were no mandatory questions, therefore the respondents could skip any questions. 
As the last question of the central part of the questionnaire (before the demographic questions) we ask the experimental question in the form of a list experiment. ${ }^{9}$

We apply the list experiment technique because public officials may resist revealing their true attitude to corruption. In a nutshell, the list experiment can be described as follows. All respondents are randomly divided into a control group and a treatment group. The respondents in the groups receive a list of situations or items and are required to indicate how many of them can be characterized in a specific manner (for example, how many of them bother the respondent). Noteworthy, that respondent is asked to indicate the number of items rather than items themselves. The list of items presented to the respondents in the treatment group is identical to that presented to the respondents in the control group, apart from one additional item - a sensitive one. As shown in the literature (Imai, 2011; Blair and Imai, 2012), if certain assumptions are satisfied ${ }^{10}$, the difference in the average number of items between the treatment and the control groups is an unbiased estimator of the population probability to choose the sensitive item. At the same time, the respondents do not directly reveal their answer to the sensitive item $^{11}$, and therefore, may not be afraid to reveal their true opinion about it. This technique also allows the use of several treatment groups by comparing each treatment group with the control group. List experiment as a part of in-person or online survey is widely used in the literature (Frye et al., 2018; Gingerich et al., 2016; Glynn, 2013).

We used three different treatments in our experiment. The question and the items for each group are listed in Table 1.

\footnotetext{
${ }^{9}$ Question 14 of Questionnaire in Online Appendix

${ }^{10}$ i) Treatment assignment is randomized; ii) the sensitive item added to the list does not influence the probabilities of the other items being selected; and iii) the respondents reveal their true opinions.

${ }^{11}$ Unless they choose maximum available items or zero items that directly indicate their choice about the sensitive question.
} 
Table 1. The experimental question

Question: Based on your experience, how many of the following factors create problems for development of the public procurement system in Russia? The question is not which factors create problems but, rather, how many of them do:

\begin{tabular}{ll} 
Group & List of Items \\
\hline Control Group & a) Low competition \\
& b) Excessive regulation \\
& c) Insufficient transparency \\
& d) Low competence of procurement officials \\
\hline Treatment Group 1 & The four Control Group items and: \\
& e) Informal relationship between buyers and suppliers \\
\hline Treatment Group 2 & The four Control Group items and: \\
& e) Corruption of buyers \\
\hline Treatment Group 3 & The four Control Group items and: \\
& e) Corruption of suppliers \\
\hline
\end{tabular}

Notes: Respondents in the control group have four items and respondents in the treatment groups have five items.

As seen from Table 1, the option 'Informal relationships between buyers and suppliers' was added to the list of potential problems in public procurement development in Treatment Group 1. This item was intended to capture to what extent the respondents are aware that such informal relationships always precede corrupt engagements. The 'Corruption of buyers' option was added in Treatment Group 2 to concentrate on the attitude to corruption of procurers. Because the problem of corruption is intensively discussed by Russian media, we expected many respondents to admit the existence of corruption, but prefer to shift the blame for it on their business counterparts. Therefore, we introduced Treatment Group 3 with a 'Corruption of suppliers' option.

\subsection{Data}

To conduct the survey with list experiment as one of questions, we collected a list of bureaucrats' emails in more than 8 million announcements of public procurement auctions from 2014-2016 in Russia. ${ }^{12}$ The source of these email is the official website www.zakupki.gov.ru. These emails are published for the needs of suppliers to contact public buyers for clarification questions about announcements. This allows to consider

\footnotetext{
${ }^{12}$ Some of the emails were distorted (for example Russian letters were used instead of English). We do not analyze this phenomenon in the current paper, but replace the most obvious 'mistakes' to obtain valid emails.
} 
these emails as official ones. From the population of these emails, we selected the emails that satisfy the following two conditions:

- the email satisfies the 'canonical' structure, 'XXX@XXX.ru' (or similar but with ending '.com');

- the email was published at least 10 times from 2014-2016 in auction announcements, including at least one publication in 2016.

The first condition eliminates the emails that were ex-ante incorrect; the second condition limits the sample to officials who might potentially be considered reliable and competent enough in public procurement. Thus, we got a list of 129,289 emails of different bureaucrats from different public entities that we consider to be the population of competent public buyers. We stratify open data about public buyers into three categories: (i) centralized agencies, who conduct procurement for regional or municipal public entities; (ii) public buyers with three-years average procurement expenditure below the overall median of annual expenditure among all public buyers ${ }^{13}$; (iii) public buyers with three-years average procurement expenditure above this median. Behavior of centralized agencies might be different from the one of basic public entity, since centralized agencies buy for other public organizations rather than for their own needs. Therefore, we create the separate strata for them. In each stratum, we randomly assigned each email to one of four groups: one control group and three treatment groups.

For the population of 129,289 emails, we sent cover letters with a link to the online survey. We conducted the survey at the online platform Anketolog (anketolog.ru), the Russian analogue of SurveyMonkey. ${ }^{14}$ As a reward for completing the survey (not necessarily entirely), we allowed the respondents to write an email address at the end of the survey. We informed them that we would use it to send them the analytical results of the survey.

We received 1251 replies, i.e. the response rate is around 1\%. ${ }^{15}$ Among 1251 respondents, 1211 respondents replied to the experimental question. For the main analysis, we filter out some unreliable observations due to several reasons. First,

\footnotetext{
${ }^{13}$ The median of annual expenditure is around 8 M RUB, or equivalently $133 \mathrm{~K}$ USD.

${ }^{14}$ We deliberately do not use SurveyMonkey, as foreign based online platforms can deter participation of public bureaucrats in the survey.

${ }^{15}$ Such response rate is a normal one for online surveys of populations that usually have the response rate between $0.5 \%-3 \%$. Moreover, as we discuss below it is not the response rate that matters, but the representativeness of the final sample to the population.
} 
following the previous literature, we excluded 7 observations from Chechnya, Ingushetia, Dagestan republics, because people living there may not feel secure enough to sincerely answer the questions of the survey, including the sensitive question, even if they are asked indirectly (Enikolopov et al., 2011; Mirkina, 2017). Next, we excluded 20 observations from Crimea and Sevastopol, because these two regions were attached to Russia only in 2014 and the unified regulation of public procurement was introduced there much later. Given the nature of the sensitive question, we also excluded 12 answers from the respondents with either too little (less than one year) or too much (more than 25 years) experience in public procurement. ${ }^{16}$ Thus, our final sample consists of 1,172 observations.

The descriptive statistics of respondents' characteristics in our sample are provided in Table A1 of Appendix A. Table A1 shows that male respondents constitute $28 \%$ of the sample. Respondents with positions "procurement coordinator or specialist" constitute $52 \%$ of the sample, "head of a division" - $28 \%$, "head of a department or deputy CEO" - 20\%. Henceforth, we call "head of a division" and "head of a department or deputy CEO" as high-ranked position, while "procurement coordinator or specialist" as lowranked position. Average experience of respondents with public procurement is 5.6 years. Respondents have age between 21 and 40 years in $49 \%$ of cases. Respondents work in small-sized organization (less than 100 workers) in 69\% of cases, mediumsized organization (101-250 workers) and large-sized organization (at least 251 workers) in $31 \%$ cases each. These organization are of the federal subordination level in $18 \%$ of cases, regional and municipal subordination in $24 \%$ and $58 \%$ of cases, respectively. They are of the education activity in $33 \%$ of cases, healthcare - $13 \%$, public administration $-27 \%$.

\subsection{Assumptions}

In the rest of this section we discuss assumptions for the list experiment, their validity for our sample and the sample's representativeness of the population. Recall, there are three main assumptions for the difference in mean to be interpreted causally under list

\footnotetext{
${ }^{16}$ The lower boundary helps exclude bureaucrats that are not experienced enough, and the upper boundary is established to eliminate three obvious outliers of 33, 37 and 45 years of experience. It was only in 1992 when post-soviet Russian public procurement system was initiated by the Law of the Russian Federation 'On supply of goods for public needs'.
} 
experiment technique: i) treatment assignment is randomized; ii) the sensitive item added to the list does not influence the probabilities of the other items being selected; and iii) the respondents reveal their true opinions.

The first assumption is achieved through the stratification and within strata randomization with respect to the population of 129,289 emails. However, there is a concern that self-selection can distort this initial randomization. Therefore, we test the quality of randomization in the final sample. The good randomization implies that the control group and the treatment groups must have no significant differences in observable respondents' characteristics. We chose demographic characteristics to examine whether the randomization was done properly: gender, position, experience in public procurement, age group, size of public organization, subordination level, economic activity. The balance statistics for these characteristics are provided in Table A2 of Appendix A. The balance statistics show that the distribution of respondents among the control and the treatment groups can be considered random. Indeed, according to all these characteristics, the mean differences are insignificant at 5\% level and almost for all of them mean differences are insignificant at $10 \%$ level $^{17}$.

With respect to the second assumption, there is no direct test for it. To address this concern, for respondents from treatment groups we added the sensitive item as the last option among all others. Thus, the control (non-sensitive) items should be observed by respondents before they observe the sensitive item. For comparison of the experiment results between different groups (e.g. between men and women), we should also be sure that control items are chosen with equal probabilities by respondents from these groups. The standard t-test for control group shows that there is no significant difference in the average number of chosen items between i) men and women (p-value is 0.46) and ii) low- and high-ranked bureaucrats ( $\mathrm{p}$-value is 0.47 ). These results imply that the control (non-sensitive) items are chosen with equal probabilities by these groups.

Another concern is that respondents can understand sensitive item differently. We did not give the respondents a definition of corruption due to two reasons. First, the term 'corruption' is everyday in the Russian media, and cases of corruption are omnipresent in Russian public procurement. Therefore, the bureaucrats working with public

\footnotetext{
${ }^{17}$ As Gerber and Green (2012: 108-109) propose, regression analysis can mitigate the disbalance in some characteristics, which we also present as robustness check.
} 
procurement are aware of its meaning and consequences, possibly more than regular people. ${ }^{18}$ Second, providing a precise definition may alert the respondents, and they may not give sincere answers.

As for the third assumption, there is no direct test for it either. However, we have the following reasons to believe that this assumption holds. First, we did not violate privacy of the respondents. We suggested to report an email, but only voluntarily and not necessarily official. Second, the ceiling and floor effects (Blair and Imai, 2012) do not change the main results. Floor effect ${ }^{19}$ is not a problem for our estimates because the control items are likely to be chosen, and only 4 out of 298 respondents (1.34\%) in the control group reported zero. To explore the possible ceiling effect ${ }^{20}$, we first note that presence of ceiling effect yields underestimation, i.e. our results of the list experiment can be considered as lower bound for the true attitude to corruption. Second, after the presentation of main results, we demonstrate that upper bound for the attitude is not substantially different.

There is also a possible concern of self-selection into survey participation because of the experimental question. This concern is negligible because of two reason. First, the experimental question is the last question of the central part and it is before the demographic part, so the respondents are not self-selected into the survey participation because of this question. Second, among 1251 replies, 1211 respondents answered to the experimental question. And those 40 respondents who skip the experimental question fill just $23 \%$ of the questionnaire on average, so they are self-selected not to answer the experimental question not because of the experimental question per se.

Assumptions i)-iii) guarantee that the difference in mean estimator is unbiased. However, they are irrelevant to understand the external validity of the estimates. To understand the external validity of results, we examine how our final sample is related to the population of bureaucrats to which we sent emails. We use different

${ }^{18}$ For example, the survey conducted by the Foundation of Public Opinion on everyday corruption in Russia did not provide the definition for the respondents (Foundation of Public Opinion, 2011)

${ }^{19}$ Respondents may hide their true answer 0 and replace it with 1 , if they are concerned of revealing their disbelief in corruption's being a problem. Also, respondents may hide their true answer 1 and replace it with 0 , if they suspect that their answer 1 is indicative of corruption's being a problem.

${ }^{20}$ Respondents may hide their true answer 5 and replace it with 4, if they are concerned of revealing their belief in corruption's being a problem. 
characteristics to show representativeness of our sample to the population: gender of bureaucrats responsible for public procurement ${ }^{21}$, organizations' economic activity and their subordination level. The comparisons of the population with our sample are given in Table A3 of Appendix A. Both sample and population include $72 \%$ of women. Organizations from education are $4 \%$ underrepresented in the sample with respect to population, while organizations from healthcare and public administration are well represented. Organizations of federal subordination are 5\% overrepresented in the sample, regional subordinated organizations are well represented, and organizations of municipal subordination are 5\% underrepresented with respect to population. Overall, the sample is well representative with respect to the population, so the results of list experiment can be extended to the population.

\section{Results}

Table 2 shows the estimates of the probabilities of choosing the sensitive item ${ }^{22}$. Specifically, $25 \%$ of the respondents consider informal relationships to be a problem of public procurement development in Russia, $29 \%$ of the respondents consider the corruption of buyers to be a problem, and $42 \%$ of the respondents consider the corruption of suppliers to be a problem. All these estimates are significant at $1 \%$ level.

These results can be compared to measures of corruption perception in Russia created through surveys among the workers of private sector. The results of a business survey conducted in 2009 show that corruption is thought to be a serious problem in the business environment by $21 \%$ of manufacturing firms' top managers (Avdasheva et al., 2010). The BEEPS survey report (World Bank, 2013) indicates that $33 \%$ of firms reported corruption as a 'major' or 'very severe' obstacle to doing business in 2011. At the same time, $40 \%$ of the respondents stated that corruption was not an obstacle at all. The distinction between the measures obtained in the two studies could have arisen due to the larger size of the firms in first sample and its focus on only the manufacturing sector; the BEEPS surveys confirms that smaller and nonmanufacturing firms generally

\footnotetext{
${ }^{21}$ In population, on top of the contact emails we observe full names of bureaucrats: first, middle, and last name. Endings of the first and middle name enables to confidently identify person's gender.

${ }^{22}$ These are the differences of the average number of items between the treatment groups and the control group.
} 
report higher corruption in comparison to the large firms. Corruption in the business environment is closely related to corruption in public procurement, because firms participate in auctions and execute public procurement contracts. Taking into account that there are few incentives for business to understate the existence of corruption, this means that procurement officials are well aware of the corruption. In addition, a research report of Foundation of Public Opinion in 2011 states that $51 \%$ of Russian citizens felt necessity to bribe an official and $47 \%$ are ready to give a bribe if necessary (Foundation of Public Opinion, 2011).

Noteworthy, our estimates are not a measure of the scale of corruption in public procurement per se. They are a measure of how often bureaucrats consider corruption to be a problem of public procurement development, i.e. their attitude to corruption. This distinction is important: even when corruption is omnipresent, some groups of bureaucrats may not see corruption to be a roadblock of development. Thus, they cannot contribute to breaking away from the existing vicious circle.

Table 2. Description of the answers to the sensitive question

\begin{tabular}{lrrrrr} 
Treatment & N & Mean & St. Dev & Difference & P-Value \\
\hline Control Group & 298 & 2.67 & 1.04 & & \\
\hline $\begin{array}{l}\text { 1: Informal relationships } \\
\text { between buyers and suppliers }\end{array}$ & 306 & 2.92 & 1.27 & 0.25 & $<0.01$ \\
\hline 2: Corruption of buyers & 285 & 2.96 & 1.18 & 0.29 & $<0.01$ \\
\hline 3: Corruption of suppliers & 283 & 3.09 & 1.26 & 0.42 & $<0.01$ \\
\hline
\end{tabular}

Notes: Treatment group 1 is the one with the additional choice option 'Informal relationships between buyers and suppliers', Treatment group 2 has additional option' Corruption of buyers', Treatment group 3 has additional option 'Corruption of suppliers'. The Difference column shows the difference in the mean number of chosen items between the control group and a treatment group, i.e. the probability to choose the sensitive item. The P-Value column reports the p-value in a one-sided t-test for whether the mean in a treatment group is higher than in the control group.

Following the existing literature, we examine whether the attitude to corruption depends on gender. To this end, we estimate the effect of the treatments for men and women separately ${ }^{23}$. Table 3 shows the estimates for the probabilities to choose a sensitive item with respect to gender. For men, the estimated probability for pointing out the informal relationships is $21 \%$; for corruption of buyers - $18 \%$; and for corruption of suppliers $-23 \%$ (none of them is statistically different from zero at $10 \%$ level). For women, the

\footnotetext{
${ }^{23}$ Recall, as Section $3 \mathrm{c}$ ) emphasizes, the difference between mean number of chosen items of men and women in the control groups is insignificant (p-value 0.46).
} 
estimated probabilities are $27 \%$ for informal relationships, $32 \%$ for corruption of buyers and $46 \%$ for corruption of suppliers (all significant at the 1\% level). Overall, the probability to choose a sensitive item by female in Treatment groups 2 and 3 is $1.8-2$ times higher compared to male.

Table 3. Description of the answers to the sensitive question by gender

\begin{tabular}{|c|c|c|c|c|c|c|}
\hline Gender & Treatment & $\mathbf{N}$ & Mean & St. Dev & Difference & P-Value \\
\hline \multicolumn{7}{|l|}{ Male } \\
\hline & Control Group & 84 & 2.6 & 1.08 & & \\
\hline & $\begin{array}{l}\text { 1: Informal relationships } \\
\text { between buyers and suppliers }\end{array}$ & 96 & 2.8 & 1.32 & 0.21 & 0.12 \\
\hline & 2: Corruption of buyers & 86 & 2.78 & 1.21 & 0.18 & 0.15 \\
\hline & 3: Corruption of suppliers & 62 & 2.82 & 1.18 & 0.23 & 0.12 \\
\hline \multicolumn{7}{|l|}{ Female } \\
\hline & Control Group & 211 & 2.7 & 1.02 & & \\
\hline & $\begin{array}{l}\text { 1: Informal relationships } \\
\text { between buyers and suppliers }\end{array}$ & 209 & 2.97 & 1.25 & 0.27 & $<0.01$ \\
\hline & 2: Corruption of buyers & 196 & 3.02 & 1.15 & 0.32 & $<0.01$ \\
\hline & 3: Corruption of suppliers & 220 & 3.16 & 1.28 & 0.46 & $<0.01$ \\
\hline
\end{tabular}

Notes: Treatment group 1 is the one with the additional choice option 'Informal relationships between buyers and suppliers', Treatment group 2 has additional option 'Corruption of buyers', Treatment group 3 has additional option 'Corruption of suppliers'. The Difference column shows the difference in the mean number of chosen items between the control group and a treatment group, i.e. the probability to choose the sensitive item. The P-Value column reports the $\mathrm{p}$-value in a one-sided t-test for whether the mean in a treatment group is higher than in the control group. All the test are conducted separately for male and female.

Thus, the analysis of the attitude to corruption with respect to gender suggests that female bureaucrats consider corruption to be a problem of public procurement development, while male bureaucrats do not. This heterogeneity in attitude of bureaucrats to corruption is important, but for policy recommendation it is necessary to understand to what extent these attitudes to corruption are related to the occupied positions. Indeed, promoting women can hardly be an anti-corruption policy if women are sensitive to corruption issues only at low-ranked positions, where they have little power to fight corruption and to be exposed to it. Therefore, it is important to 
understand if the results still hold for women at high-ranked position. Table 4 shows the results with respect to gender and position ${ }^{24}$.

Table 4. Average treatment effect with breakdown by gender and position

\begin{tabular}{|c|c|c|c|c|c|c|}
\hline 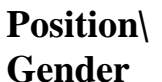 & & Female & & & Male & \\
\hline & Treatment 1 & Treatment 2 & Treatment 3 & Treatment 1 & Treatment 2 & Treatment 3 \\
\hline High- & 0.255 & 0.243 & 0.562 & 0.134 & 0.021 & 0.475 \\
\hline & $(0.05)$ & $(0.06)$ & $(0.001)$ & $(0.295)$ & $(0.465)$ & $(0.035)$ \\
\hline & Treatment 1 & Treatment 2 & Treatment 3 & Treatment 1 & Treatment 2 & Treatment 3 \\
\hline Low- & 0.321 & 0.412 & 0.422 & 0.386 & 0.407 & -0.125 \\
\hline & $(0.025)$ & $(0.005)$ & $(0.003)$ & $(0.072)$ & $(0.064)$ & $(0.682)$ \\
\hline
\end{tabular}

Notes: The table shows the differences between treatment groups and the corresponding control groups (by position and gender). Treatment 1 is the for the group with the additional choice option 'Informal relationships between buyers and suppliers', Treatment group 2 has additional option 'Corruption of buyers', Treatment group 3 has additional option 'Corruption of suppliers'. P-values in parentheses are for a one-sided t-test for comparison with the corresponding control groups (the alternative hypothesis is that the mean in a treatment group is larger than the mean in the control group). The differences can be interpreted as the proportions of the bureaucrats distinguishing the corresponding corrupt aspect within a position-gender group. The negative value of the difference in mean between the treatment group and the control group for low-ranked male is insignificant and clearly due to chance (Glynn, 2013).

For high-ranked bureaucrats the effect of the Treatment 1 ('Informal relationships') and Treatment 2 ('Corruption of buyers') is significant at 5\%-6\% level for women and insignificant for men. Moreover, the magnitude of the effects is also substantially different. Among female high-ranked officials 24.3\% (25.5\%) see 'Corruption of buyers' ('Informal relationships') to be a problem of public procurement development, while the corresponding value for high-ranked male officials is $2.1 \%$ (13.4\%) respectively. Noteworthy, that both male and female high-ranked bureaucrats admit 'Corruption of supplier' - the effects are significant at 5\% level and are comparable in size (56.2\% for female and $47.5 \%$ for male bureaucrats). These results suggest that high-ranked female bureaucrats consider corruption to be a problem at both sides, buyers and suppliers, while high-ranked male bureaucrats do not admit that corruption of buyers can create a problem of procurement development.

\footnotetext{
${ }^{24}$ Table A4 of Appendix shows the distribution of observations by gender-position.
} 
At low-ranked positions the effect of the Treatment 1 ('Informal relationships') and Treatment 2 ('Corruption of buyers') is significant at $10 \%$ level for both women and men. Magnitudes of the effects are also comparable: for Treatment $1-32.1 \%$ for women vs. $38.6 \%$ for men, for Treatment $2-41.2 \%$ for women vs. $40.7 \%$ for men. The effect of Treatment 3 is significant at $1 \%$ level for women (42.2\%), and insignificant for men.

In sum, both male and female bureaucrats at low-ranked positions consider corruption to be a problem of public procurement development, while at high-ranked positions only women demonstrate negative attitude to corruption. Therefore, promoting women can be an efficient anti-corruption policy.

\section{Robustness check}

Random assignment of treatment is one of the requirements for obtaining unbiased estimates while using the list experiment approach. In Table A2 we show all demographic characteristics are well balanced - the difference in mean of these characteristics between control and treatment groups are insignificant at 5\% level. However, there some characteristics that are imbalanced at 10\% level: age for Treatment 1, position for Treatment 2, gender for Treatment 3. This imbalance can make the difference in mean estimate to be biased. To correct for the bias we use the approach proposed by Gerber and Green (2012, pp. 108-109) for a failure of randomization of treatment that happens by chance. In our case, the failure of randomization happened because not all the respondents answered to the questionnaire. According to Gerber and Green, the variables we use for testing for the randomization are covariates; to get unbiased estimates the analysis should use these covariates as controls in regression analysis. To do that, we do OLS regression with the answer to the experimental question as the dependent variable, and treatment, gender, their multiplications as well as all other demographic characteristics as explanatory variables. For each treatment we run separate regression, where sample includes observations from the control group and the treatment group under study.

Table A5 demonstrates the regression results. Columns 1-3 show total effects of Treatments 1-3 respectively. They are all significant at 1\% level and 6-7 percentage points higher than estimates of Table 2. The reduction of number of observations in 
Table $A 5^{25}$ is due to lack of respondents' answers to all demographic questions that we use as controls. Columns 4-6 demonstrate the effects of treatments 1-3 separately for men and women and should be compared with Table 3. Similar to initial findings of Table 3, treatment effects are insignificant for men, but significant for women at $1 \%$ level.

Table A6 replicates the results of Table A5 (columns 4-6) with breakdown by position level. Columns 1-3 (4-6) of Table A6 show the treatment effects for men and women with low-ranked positions (high-ranked positions). The magnitude of effects is similar to the one in Table 4, though we do not observe significant effect for male bureaucrats at low-ranked position. More important, the main results for women at high-ranked position hold for all treatments at $1 \%-5 \%$ level.

As was mentioned in Section $3 \mathrm{c}$ ), the presence of ceiling effect may cause underestimation of the true attitude to corruption. This is neither a problem for women, nor for men at low-ranked position (Treatments 1 and 2), as these groups of respondents are sensitive to corruption even with underestimated effect, i.e. the true attitude is even higher for them. However, if underestimation of attitude to corruption is substantial for high-ranked men, we may wrongly conclude their lack of sensitivity to corruption. In what follows we construct upper bound for the true attitude to corruption by eliminating ceiling effect. We replaced all answers 4 with 5 in the treatment groups and replicated the analysis of Table 4. The results are presented in Table A7. As one expects, all estimates of treatment effects increases, though accounting for possible ceiling effect does not change the results for male bureaucrats at high-ranked position: the effects of Treatments 1 and 2 are insignificant, while effect of Treatment 3 is significant despite lower number of observations compared to Treatments 1 and 2 (see Table A4).

\section{Conclusion}

Many studies consider the scale of corruption in developing countries and its negative effects. However, most of these studies do not answer the question of why, under an existing corrupt equilibrium, bureaucrats or politicians would make efforts to reduce corruption. Understanding the heterogeneity of bureaucrats in their attitude to

\footnotetext{
${ }^{25}$ For example, Table A5 column 1 has 537 obs., while the control group has 298 obs. and Treatment 1 group has 306 obs.
} 
corruption can help policy designers to identify groups of bureaucrats that can be the basis to fight corruption in imperfect institutional environments.

Following this approach, this article studies the differences in bureaucrats' attitudes to corruption among public procurement officials in Russia. A list experiment technique is applied due to the sensitivity of direct questions on corruption for respondents. The results suggest that female bureaucrats are likely to consider corruption a public procurement roadblock and male bureaucrats are not. This result holds for women even at high positions, while high-ranked male bureaucrats do not consider corruption of bureaucrats to be a problem of public procurement development.

Despite that these results are in line with some of the previous findings about gender differences regarding perceptions of corrupt activities, we detect heterogeneity in the attitude to corruption of real-life bureaucrats. That makes the results more reliable than those obtained through surveys of consumers of public services (citizens and firms) or laboratory experiments. Thus, with a focus on the 'insiders' of the bureaucratic system and by applying the list experiment technique, we provide new insight into the attitude to corruption by different groups of officials. We can conclude that extending career opportunities for female officials may become an indirect tool to limit corruption in developing countries because direct methods of fighting corruption often clash against the resistance of vested interests involved in corrupt schemes. 


\section{REFERENCES}

Ades, A., Di Tella, R. (1999). Rents, Competition, and Corruption. American Economic Review, 89(4), 982-993. https://doi.org/10.1257/aer.89.4.982

Afridi, F., Iversen, V., Sharan, M. R. (2017). Women Political Leaders, Corruption, and Learning: Evidence from a Large Public Program in India. Economic Development and Cultural Change, 66(1), 1-30. https://doi.org/10.1086/693679

Aidt, T. S. (2009). Corruption, institutions, and economic development. Oxford Review of Economic Policy, 25(2), 271-291. https://doi.org/10.1093/oxrep/grp012

Alatas, V., Cameron, L., Chaudhuri, A., Erkal, N., Gangadharan, L. (2009). Gender, Culture, and Corruption: Insights from an Experimental Analysis. Southern Economic Journal, 75(3), 663-680.

Alhassan-Alolo, N. (2007). Gender and corruption: Testing the new consensus. Public Administration and Development, 27(3), 227-237. https://doi.org/10.1002/pad.455

Andreyanov, P., Davidson, A., Korovkin, V. (2017). Detecting Auctioneers' Corruption: Evidence from Russian Procurement Auctions.

Armantier, O., Boly, A. (2008). Can Corruption be Studied in the Lab? Comparing a Field and a Lab Experiment (SSRN Scholarly Paper ID 1324120). Social Science Research Network. https://papers.ssrn.com/abstract=1324120

Auriol, E., Straub, S., Flochel, T. (2016). Public Procurement and Rent-Seeking: The Case of Paraguay. World Development, 77, 395-407. https://doi.org/10.1016/j.worlddev.2015.09.001

Avdasheva, S., Dolgopyatova, T., Golikova, V., Gonchar, K., Kuznetsov, B., Yakovlev, A. (2010). Predprijatija i rynki v 2005-2009 godah: Itogi dvuh raundov obsledovanija rossijskoj obrabatyvajushhej promyshlennosti. [Industries and markets in 20052009: Results of two rounds of studying Russian manufacturing industry].

Banerjee, R. (2016). On the interpretation of bribery in a laboratory corruption game: Moral frames and social norms. Experimental Economics, 19(1), 240-267. https://doi.org/10.1007/s10683-015-9436-1 
Barr, A., Lindelow, M., Serneels, P. (2009). Corruption in public service delivery: An experimental analysis. Journal of Economic Behavior \& Organization, 72(1), 225239. https://doi.org/10.1016/j.jebo.2009.07.006

Becker, S. O., Boeckh, K., Hainz, C., Woessmann, L. (2016). The Empire Is Dead, Long Live the Empire! Long-Run Persistence of Trust and Corruption in the Bureaucracy. The Economic Journal, 126(590), 40-74. https://doi.org/10.1111/ecoj.12220

Best, M., Hjort, J., Szakonyi, D. (2017). Individuals and Organizations as Sources of State Effectiveness (SSRN Scholarly Paper ID 2961055). Social Science Research Network. https://papers.ssrn.com/abstract=2961055

Blair, G., Imai, K. (2012). Statistical Analysis of List Experiments. Political Analysis, 20(1), 47-77.

Bosio, E., Djankov, S., Glaeser, E. L., Shleifer, A. (2020). Public Procurement in Law and Practice (Working Paper No. 27188; Working Paper Series). National Bureau of Economic Research. https://doi.org/10.3386/w27188

Breen, M., Gillanders, R., Mcnulty, G., Suzuki, A. (2017). Gender and Corruption in Business. The Journal of Development Studies, 53(9), 1486-1501. https://doi.org/10.1080/00220388.2016.1234036

Brierley, S. (2020). Unprincipled Principals: Co-opted Bureaucrats and Corruption in Ghana. American Journal of Political Science, 64(2), 209-222. https://doi.org/10.1111/ajps.12495

Brollo, F., Troiano, U. (2016). What happens when a woman wins an election? Evidence from close races in Brazil. Journal of Development Economics, 122, 28-45. https://doi.org/10.1016/j.jdeveco.2016.04.003

Chand, S., Moene, K. (1997). Controlling Fiscal Corruption. IMF Working Paper: Controlling Fiscal Corruption, 97(100). https://doi.org/10.5089/9781451852363.001

Chong, E., Klien, M., Saussier, S. (2013). The quality of governance and the use of negotiated procedures: Some (un)-surprising evidence from the European Union (Working paper). 
Dávid-Barrett, E., Fazekas, M. (2020). Anti-corruption in aid-funded procurement: Is corruption reduced or merely displaced? World Development, 132, 105000. https://doi.org/10.1016/j.worlddev.2020.105000

Debski, J., Jetter, M., Mösle, S., Stadelmann, D. (2018). Gender and corruption: The neglected role of culture. European Journal of Political Economy, 55, 526-537. https://doi.org/10.1016/j.ejpoleco.2018.05.002

Dollar, D., Fisman, R., Gatti, R. (2001). Are women really the "fairer" sex? Corruption and women in government. Journal of Economic Behavior \& Organization, 46(4), 423429. https://doi.org/10.1016/S0167-2681(01)00169-X

Enikolopov, R., Petrova, M., Zhuravskaya, E. (2011). Media and Political Persuasion: Evidence from Russia. The American Economic Review, 101(7), 3253-3285.

Esarey, J., Chirillo, G. (2013). "Fairer Sex” or Purity Myth? Corruption, Gender, and Institutional Context. Politics \& Gender, 9(4), 361-389. https://doi.org/10.1017/S1743923X13000378

Esarey, J., Schwindt-Bayer, L. A. (2018). Women's Representation, Accountability and Corruption in Democracies. British Journal of Political Science. https://doi.org/10.1017/S0007123416000478

Ferraz, C., Finan, F. (2011). Electoral Accountability and Corruption: Evidence from the Audits of Local Governments. American Economic Review, 101(4), 1274-1311. https://doi.org/10.1257/aer.101.4.1274

Foundation of Public Opinion. (2011). Sostojanie bytovoj korrupcii v Rossijskoj Federacii [The state of everydate corruption in the Russian Federation]. http://www.indem.ru/corrupt/doklad_cor_INDEM_FOM_2010.pdf

Frank, B., Lambsdorff, J. G., Boehm, F. (2011). Gender and Corruption: Lessons from Laboratory Corruption Experiments. The European Journal of Development Research, 23(1), 59-71.

Frye, T., Reuter, O. J., Szakonyi, D. (2018). Hitting Them With Carrots: Voter Intimidation and Vote Buying in Russia. British Journal of Political Science, 1-25. https://doi.org/10.1017/S0007123416000752 
Gerber, A. S., Green, D. P. (2012). Field Experiments: Design, Analysis, and Interpretation (1st edition). W. W. Norton \& Company.

Gingerich, D. W., Oliveros, V., Corbacho, A., Ruiz-Vega, M. (2016). When to Protect? Using the Crosswise Model to Integrate Protected and Direct Responses in Surveys of Sensitive Behavior. Political Analysis, 24(2), 132-156. https://doi.org/10.1093/pan/mpv034

Glynn, A. N. (2013). What Can We Learn with Statistical Truth Serum? Design and Analysis of the List Experiment. Public Opinion Quarterly, 77(S1), 159-172. https://doi.org/10.1093/poq/nfs070

Golden, M. A., Picci, L. (2005). Proposal for a New Measure of Corruption, Illustrated with Italian Data. Economics \& Politics, 17(1), 37-75. https://doi.org/10.1111/j.1468-0343.2005.00146.x

Gorodnichenko, Y., Sabirianova Peter, K. (2007). Public sector pay and corruption: Measuring bribery from micro data. Journal of Public Economics, 91(5), 963-991. https://doi.org/10.1016/j.jpubeco.2006.12.003

Hao, Y., Chang, C.-P., Sun, Z. (2017). Women and corruption: Evidence from multinational panel data. Quality \& Quantity, 1-22. https://doi.org/10.1007/s11135017-0530-7

Hellman, J. S., Jones, G., Kaufmann, D. (2003). Seize the state, seize the day: State capture and influence in transition economies. Journal of Comparative Economics, 31(4), 751-773. https://doi.org/10.1016/j.jce.2003.09.006

Imai, K. (2011). Multivariate Regression Analysis for the Item Count Technique. Journal of the American Statistical Association, 106(494), 407-416. https://doi.org/10.1198/jasa.2011.ap10415

Jha, C. K., Sarangi, S. (2018). Women and corruption: What positions must they hold to make a difference? Journal of Economic Behavior \& Organization, 151, 219-233. https://doi.org/10.1016/j.jebo.2018.03.021

Lambert-Mogiliansky, A., Sonin, K. (2006). Collusive Market Sharing and Corruption in Procurement. Journal of Economics \& Management Strategy, 15(4), 883-908. https://doi.org/10.1111/j.1530-9134.2006.00121.x 
Macrae, J. (1982). Underdevelopment and the economics of corruption: A game theory approach. World Development, 10(8), 677-687. https://doi.org/10.1016/0305750X(82)90093-6

Mauro, P. (1995). Corruption and Growth. The Quarterly Journal of Economics, 110(3), $681-712$.

Menezes, F. M., Monteiro, P. K. (2006). Corruption and auctions. Journal of Mathematical Economics, 42(1), 97-108. https://doi.org/10.1016/j.jmateco.2005.04.002

Mirkina, I. (2017). Regions of Russia in Comparative Perspective: Introducing a New Dataset (SSRN Scholarly Paper ID 2969950). Social Science Research Network. https://papers.ssrn.com/abstract=2969950

Mironov, M., Zhuravskaya, E. (2016). Corruption in Procurement and the Political Cycle in Tunneling: Evidence from Financial Transactions Data. American Economic Journal: Economic Policy, 8(2), 287-321. https://doi.org/10.1257/pol.20140188

Mookherjee, D., Png, I. (1995). Corruptible Law Enforcers: How Should They Be Compensated? Economic Journal, 105(428), 145-159.

Olken, B. A. (2006). Corruption and the costs of redistribution: Micro evidence from Indonesia. Journal of Public Economics, 90(4), 853-870. https://doi.org/10.1016/j.jpubeco.2005.05.004

Ponomariov, B., Kisunko, G. (2018). Overcoming the Impact of Corruption through Diligence: The Experience of Russian Female Managers. International Journal of Public Administration, 41(12), 971-985. https://doi.org/10.1080/01900692.2017.1316287

Rivas, M. F. (2013). An Experiment on Corruption and Gender. Bulletin of Economic Research, 65(1), 10-42. https://doi.org/10.1111/j.1467-8586.2012.00450.x Russia-BEEPS at a glance 2011 (No. 75568; pp. 1-28). (2013). The World Bank. http://documents.worldbank.org/curated/en/402491468336533488/Russia-BEEPSat-a-glance-2011

Schulze, G. G., Sjahrir, B. S., Zakharov, N. (2016). Corruption in Russia. The Journal of Law and Economics, 59(1), 135-171. https://doi.org/10.1086/684844 
Sidorkin, O., Vorobyev, D. (2017). Political cycles and corruption in Russian regions. European Journal of Political Economy. https://doi.org/10.1016/j.ejpoleco.2017.05.001

Stensöta, H., Wängnerud, L. (2018). Gender and Corruption: Historical Roots and New Avenues for Research. Springer.

Stensöta, H., Wängnerud, L., Svensson, R. (2015). Gender and Corruption: The Mediating Power of Institutional Logics. Governance, 28(4), 475-496. https://doi.org/10.1111/gove.12120

Sung, H.-E. (2012). Women in government, public corruption, and liberal democracy: A panel analysis. Crime, Law and Social Change, 58(3), 195-219. https://doi.org/10.1007/s10611-012-9381-2

Swamy, A., Knack, S., Lee, Y., Azfar, O. (2001). Gender and corruption. Journal of Development Economics, 64(1), 25-55.

Szakonyi, D. (2018). Businesspeople in Elected Office: Identifying Private Benefits from Firm-Level Returns. American Political Science Review, 112(2), 322-338. https://doi.org/10.1017/S0003055417000600

Szucs, F. (2017). Discretion and Corruption in Public Procurement. Mimeo, 1-42.

Tanzi, V., Davoodi, H. (1998). Corruption, Public Investment, and Growth. In The Welfare State, Public Investment, and Growth (pp. 41-60). Springer, Tokyo. https://doi.org/10.1007/978-4-431-67939-4_4

Tkachenko, A., Esaulov, D. (2020). Autocratic governors in public procurement. European Journal of Political Economy, 61, 1-18. https://doi.org/10.1016/j.ejpoleco.2019.101825

Tkachenko, A., Yakovlev, A., Kuznetsova, A. (2017). 'Sweet deals': State-owned enterprises, corruption and repeated contracts in public procurement. Economic Systems, 41(1), 52-67.

Torgler, B., \& Valev, N. T. (2010). Gender and Public Attitudes Toward Corruption and Tax Evasion. Contemporary Economic Policy, 28(4), 554-568. https://doi.org/10.1111/j.1465-7287.2009.00188.x 
Transparency International. (2018). Corruption Perceptions Index 2017.

https://files.transparency.org/content/download/2185/13756/file/2017_CPI_Brochur e_EN.PDF

Vijayalakshmi, V. (2008). Rent-Seeking and Gender in Local Governance. The Journal of Development Studies, 44(9), 1262-1288.

https://doi.org/10.1080/00220380802265611

Wei, S.-J. (1999). Corruption in Economic Development: Beneficial Grease, Minor Annoyance, or Major Obstacle? (SSRN Scholarly Paper ID 604923). Social Science Research Network. https://papers.ssrn.com/abstract=604923 


\section{Appendix}

Table A1. Descriptive statistics

\begin{tabular}{lccccc} 
Statistic & $\mathbf{N}$ & Mean & St. Dev. & Min & Max \\
\hline Male & 1164 & 0.282 & 0.45 & 0 & 1 \\
Female & 1164 & 0.718 & 0.45 & 0 & 1 \\
Low-ranked position & 1154 & 0.518 & 0.5 & 0 & 1 \\
High-ranked position & 1154 & 0.482 & 0.5 & 0 & 1 \\
Experience (years) & 1079 & 5.571 & 3.84 & 1 & 25 \\
Age between 21 and 40 & 1172 & 0.493 & 0.5 & 0 & 1 \\
Age more than 40 & 1172 & 0.502 & 0.5 & 0 & 1 \\
Small-sized organization & 1172 & 0.689 & 0.463 & 0 & 1 \\
Large and medium sized & & & & & \\
organization & 1172 & 0.311 & 0.463 & 0 & 1 \\
Municipal subordination & 1160 & 0.584 & 0.493 & 0 & 1 \\
Regional subordination & 1160 & 0.239 & 0.427 & 0 & 1 \\
Federal subordination & 1160 & 0.177 & 0.382 & 0 & 1 \\
Public administration activity & 1172 & 0.269 & 0.444 & 0 & 1 \\
Healthcare activity & 1172 & 0.133 & 0.34 & 0 & 1 \\
Education activity & 1172 & 0.333 & 0.471 & 0 & 1 \\
Other activity & 1172 & 0.265 & 0.442 & 0 & 1
\end{tabular}

Note. The table reports the descriptive statistics for the sample, including four groups of respondents - one control and three treatment groups. Male, Female and Age dummy variables show a respondent's gender and age group respectively. Low-ranked position is a dummy for a procurement coordinator (specialist); Highranked position is a dummy for a head of division, head of department or a deputy CEO. Experience stands for experience in public procurement (in years). Small-sized organization is an organization with at most 100 workers; Large- and medium- sized organization has more than 100 workers. 
Table A2. Balance statistics by control and treatment groups

\begin{tabular}{|c|c|c|c|c|c|c|c|c|c|c|}
\hline & \multirow{2}{*}{$\begin{array}{r}\begin{array}{r}\text { Control } \\
\text { Group }\end{array} \\
\text { Mean }\end{array}$} & \multicolumn{3}{|c|}{$\begin{array}{c}\text { Treatment } 1 \text {. Informal } \\
\text { relationships }\end{array}$} & \multicolumn{3}{|c|}{$\begin{array}{c}\text { Treatment 2. Corruption } \\
\text { of buyers }\end{array}$} & \multicolumn{3}{|c|}{$\begin{array}{c}\text { Treatment 3. Corruption } \\
\text { of suppliers }\end{array}$} \\
\hline & & Mean & Difference & P-Value & Mean & Difference & P-Value & Mean & Difference & P-Value \\
\hline Female & 0.72 & 0.69 & -0.03 & 0.42 & 0.7 & -0.02 & 0.6 & 0.78 & 0.06 & 0.07 \\
\hline High ranked position & 0.52 & 0.48 & -0.04 & 0.32 & 0.45 & -0.07 & 0.09 & 0.46 & -0.06 & 0.15 \\
\hline Experience (years) & 5.63 & 5.42 & -0.21 & 0.51 & 5.61 & -0.02 & 0.94 & 5.64 & 0.01 & 0.99 \\
\hline Age more than 40 & 0.52 & 0.45 & -0.07 & 0.09 & 0.5 & -0.02 & 0.54 & 0.53 & 0.01 & 0.81 \\
\hline $\begin{array}{l}\text { Large and medium sized } \\
\text { organization }\end{array}$ & 0.3 & 0.31 & 0.01 & 0.76 & 0.33 & 0.03 & 0.42 & 0.3 & 0 & 0.89 \\
\hline Municipal subordination & 0.56 & 0.59 & 0.03 & 0.42 & 0.59 & 0.03 & 0.44 & 0.61 & 0.05 & 0.2 \\
\hline Regional subordination & 0.23 & 0.26 & 0.03 & 0.5 & 0.23 & 0 & 0.9 & 0.24 & 0.01 & 0.86 \\
\hline Public administration activity & 0.26 & 0.26 & 0 & 0.86 & 0.28 & 0.02 & 0.55 & 0.28 & 0.02 & 0.45 \\
\hline Healthcare activity & 0.11 & 0.13 & 0.02 & 0.45 & 0.14 & 0.03 & 0.34 & 0.16 & 0.05 & 0.11 \\
\hline Education activity & 0.35 & 0.35 & 0 & 0.99 & 0.33 & -0.02 & 0.63 & 0.29 & -0.06 & 0.11 \\
\hline
\end{tabular}

Note. The table reports the balance statistics for the sample. The Difference columns show the difference in the mean values between the corresponding treatment groups and the control group. The P-Value columns report the p-values of two-sided t-tests for equality between the means of variable in the control group and in the corresponding treatment group. Explanation of variables is provided at the note of Table A1. 
Table A3. Comparison of the sample and population by different characteristics

\begin{tabular}{llcc}
\hline Characteristic & Value & Sample & Population \\
\hline Gender & Female & $71.8 \%$ & $71.9 \%$ \\
\hline Economic & Education & $33.3 \%$ & $37.6 \%$ \\
activity & Healthcare & $13.3 \%$ & $14.4 \%$ \\
& Public administration & $26.9 \%$ & $27.5 \%$ \\
\hline Subordination & Federal & $17.7 \%$ & $12.6 \%$ \\
level & Regional & $23.9 \%$ & $24.0 \%$ \\
& Municipal & $58.4 \%$ & $63.3 \%$ \\
\hline
\end{tabular}

Note. The table shows a comparison of sample and population of respondents. The population parameters are based on the analysis of organizations and their workers to whom we sent emails. Information about organizations is published at the official website of Russian public procurement zakupki.gov.ru/epz/organization. Sample parameters are based on the analysis of answers of respondents. Approximately one percent of the respondents in the sample did not state the subordination level of their organization.

\begin{tabular}{lcccccccc} 
& \multicolumn{3}{c}{ Table A4. Number of observations by gender and position } \\
Position\Gender & \multicolumn{9}{c}{ Female } & \multicolumn{4}{c}{ Male } \\
\multirow{2}{*}{ High-ranked } & Contr. & Tr. 1 & Tr. 2 & Tr. 3 & Contr. & Tr. 1 & Tr. 2 & Tr. 3 \\
& 106 & 95 & 84 & 91 & 46 & 51 & 43 & 38 \\
\hline Low-ranked & Contr. & Tr. 1 & Tr. 2 & Tr. 3 & Contr. & Tr. 1 & Tr. 2 & Tr. 3 \\
& 101 & 111 & 109 & 126 & 36 & 44 & 43 & 24 \\
\hline
\end{tabular}

Notes. The table shows the number of observations of the sample with breakdown by position, gender, and treatment. 'Contr.' is for Control group, 'Tr. 1' is for the group with the additional choice option 'Informal relationships between buyers and suppliers' (Treatment 1), 'Tr. 2' is for 'Corruption of buyers' (Treatment 2), and 'Tr. 3' is for corruption of suppliers (Treatment 3). High- and Low- ranked lines are for the corresponding ranks of positions. 
Table A5. List experiment results in regression setting

Dependent variable: answer to the experimental question

\begin{tabular}{|c|c|c|c|c|c|c|}
\hline & (1) & (2) & (3) & (4) & (5) & (6) \\
\hline Treatment & $\begin{array}{l}0.311^{* * *} \\
(0.102)\end{array}$ & $\begin{array}{l}0.354^{* * *} \\
(0.099)\end{array}$ & $\begin{array}{l}0.496^{* * *} \\
(0.103)\end{array}$ & & & \\
\hline Treatment*Male & & & & $\begin{array}{l}0.294 \\
(0.197)\end{array}$ & $\begin{array}{l}0.181 \\
(0.189)\end{array}$ & $\begin{array}{l}0.261 \\
(0.198)\end{array}$ \\
\hline Treatment*Female & & & & $\begin{array}{l}0.318^{* * *} \\
(0.117)\end{array}$ & $\begin{array}{l}0.425^{* * *} \\
(0.116)\end{array}$ & $\begin{array}{l}0.574^{* * *} \\
(0.119)\end{array}$ \\
\hline Male & $\begin{array}{l}0.011 \\
(0.121)\end{array}$ & $\begin{array}{l}-0.125 \\
(0.117)\end{array}$ & $\begin{array}{l}-0.164 \\
(0.121)\end{array}$ & $\begin{array}{c}0.023 \\
(0.150)\end{array}$ & $\begin{array}{l}-0.002 \\
(0.150)\end{array}$ & $\begin{array}{l}-0.021 \\
(0.151)\end{array}$ \\
\hline Low-ranked position & $\begin{array}{l}-0.072 \\
(0.102)\end{array}$ & $\begin{array}{l}-0.041 \\
(0.104)\end{array}$ & $\begin{array}{c}-0.243^{* *} \\
(0.108)\end{array}$ & $\begin{array}{l}-0.072 \\
(0.102)\end{array}$ & $\begin{array}{l}-0.038 \\
(0.104)\end{array}$ & $\begin{array}{l}-0.249^{* *} \\
(0.108)\end{array}$ \\
\hline Experience & $\begin{array}{l}-0.011 \\
(0.016)\end{array}$ & $\begin{array}{l}-0.016 \\
(0.015)\end{array}$ & $\begin{array}{c}0.003 \\
(0.015)\end{array}$ & $\begin{array}{l}-0.011 \\
(0.016)\end{array}$ & $\begin{array}{l}-0.016 \\
(0.015)\end{array}$ & $\begin{array}{l}0.003 \\
(0.016)\end{array}$ \\
\hline Age is $21-40$ & $\begin{array}{l}-0.014 \\
(0.105)\end{array}$ & $\begin{array}{c}0.093 \\
(0.107)\end{array}$ & $\begin{array}{c}0.063 \\
(0.110)\end{array}$ & $\begin{array}{l}-0.014 \\
(0.105)\end{array}$ & $\begin{array}{l}0.091 \\
(0.107)\end{array}$ & $\begin{array}{l}0.066 \\
(0.110)\end{array}$ \\
\hline At most 100 workers & $\begin{array}{l}0.156 \\
(0.132)\end{array}$ & $\begin{array}{c}0.065 \\
(0.134)\end{array}$ & $\begin{array}{c}0.114 \\
(0.129)\end{array}$ & $\begin{array}{c}0.157 \\
(0.132)\end{array}$ & $\begin{array}{l}0.062 \\
(0.134)\end{array}$ & $\begin{array}{l}0.115 \\
(0.129)\end{array}$ \\
\hline Municipal & $\begin{array}{l}0.058 \\
(0.169)\end{array}$ & $\begin{array}{c}0.073 \\
(0.150)\end{array}$ & $\begin{array}{c}0.011 \\
(0.157)\end{array}$ & $\begin{array}{c}0.058 \\
(0.169)\end{array}$ & $\begin{array}{l}0.084 \\
(0.151)\end{array}$ & $\begin{array}{l}0.016 \\
(0.156)\end{array}$ \\
\hline Regional & $\begin{array}{l}0.095 \\
(0.179)\end{array}$ & $\begin{array}{c}0.111 \\
(0.162)\end{array}$ & $\begin{array}{c}0.086 \\
(0.162)\end{array}$ & $\begin{array}{c}0.095 \\
(0.179)\end{array}$ & $\begin{array}{l}0.123 \\
(0.162)\end{array}$ & $\begin{array}{l}0.092 \\
(0.162)\end{array}$ \\
\hline Public admin. & $\begin{array}{l}0.016 \\
(0.152)\end{array}$ & $\begin{array}{c}0.046 \\
(0.146)\end{array}$ & $\begin{array}{c}0.154 \\
(0.142)\end{array}$ & $\begin{array}{c}0.016 \\
(0.152)\end{array}$ & $\begin{array}{l}0.046 \\
(0.145)\end{array}$ & $\begin{array}{l}0.162 \\
(0.142)\end{array}$ \\
\hline Healthcare & $\begin{array}{l}-0.022 \\
(0.200)\end{array}$ & $\begin{array}{l}-0.100 \\
(0.203)\end{array}$ & $\begin{array}{c}0.162 \\
(0.195)\end{array}$ & $\begin{array}{l}-0.021 \\
(0.200)\end{array}$ & $\begin{array}{l}-0.107 \\
(0.204)\end{array}$ & $\begin{array}{l}0.169 \\
(0.193)\end{array}$ \\
\hline Education & $\begin{array}{l}0.116 \\
(0.134)\end{array}$ & $\begin{array}{c}0.092 \\
(0.132)\end{array}$ & $\begin{array}{l}0.281^{* *} \\
(0.134)\end{array}$ & $\begin{array}{c}0.116 \\
(0.134)\end{array}$ & $\begin{array}{l}0.094 \\
(0.132)\end{array}$ & $\begin{array}{l}0.287^{* *} \\
(0.134)\end{array}$ \\
\hline Constant & $\begin{array}{l}2.519^{* * *} \\
(0.221)\end{array}$ & $\begin{array}{l}2.586^{* * *} \\
(0.210)\end{array}$ & $\begin{array}{l}2.477^{* * * *} \\
(0.230)\end{array}$ & $\begin{array}{l}2.515^{* * *} \\
(0.223)\end{array}$ & $\begin{array}{l}2.541^{* * * *} \\
(0.211)\end{array}$ & $\begin{array}{l}2.429^{* * * *} \\
(0.231)\end{array}$ \\
\hline Observations & 537 & 515 & 530 & 537 & 515 & 530 \\
\hline R-squared & 0.029 & 0.039 & 0.063 & 0.029 & 0.041 & 0.066 \\
\hline
\end{tabular}

Note. The table shows estimates of treatment effect in regression setting. Dependent variable is the number of chosen items of the sensitive question in either the control or a treatment group. Columns 1-3 estimate average treatment effects for treatments 1-3 respectively. Columns 4-6 estimate average treatment effect for treatments 1-3 respectively with breakdown by gender. The control variables are: gender position, experience, age, organization size, subordination level and branch of activity. 
Table A6. List experiment results in regression setting with breakdown by gender for low and high -ranked positions

Dependent variable: answer to the experimental question

Low-ranked

High-ranked

\begin{tabular}{lcccccc} 
& $(1)$ & $(2)$ & $(3)$ & $(4)$ & $(5)$ & $(6)$ \\
\hline Treatment*Male & 0.409 & 0.351 & -0.128 & 0.201 & 0.122 & $0.583^{* *}$ \\
& $(0.290)$ & $(0.286)$ & $(0.289)$ & $(0.267)$ & $(0.248)$ & $(0.274)$ \\
Treatment*Female & $0.315^{*}$ & $0.515^{* * *}$ & $0.502^{* * *}$ & $0.326^{* *}$ & $0.329^{* *}$ & $0.662^{* * *}$ \\
& $(0.171)$ & $(0.163)$ & $(0.158)$ & $(0.163)$ & $(0.166)$ & $(0.184)$ \\
Male & 0.069 & -0.023 & 0.030 & -0.094 & -0.113 & -0.055 \\
& $(0.227)$ & $(0.230)$ & $(0.229)$ & $(0.212)$ & $(0.202)$ & $(0.209)$ \\
Experience & 0.002 & 0.023 & 0.013 & -0.020 & $-0.037^{*}$ & -0.005 \\
& $(0.025)$ & $(0.024)$ & $(0.023)$ & $(0.023)$ & $(0.020)$ & $(0.022)$ \\
Age is 21-40 & 0.081 & $0.313^{*}$ & 0.122 & -0.078 & -0.038 & -0.043 \\
& $(0.156)$ & $(0.161)$ & $(0.156)$ & $(0.152)$ & $(0.145)$ & $(0.167)$ \\
At most 100 workers & -0.148 & -0.175 & 0.302 & $0.393^{* *}$ & $0.307^{*}$ & -0.078 \\
Municipal & $(0.215)$ & $(0.233)$ & $(0.183)$ & $(0.172)$ & $(0.158)$ & $(0.186)$ \\
& 0.384 & 0.286 & 0.072 & -0.229 & -0.102 & -0.068 \\
Regional & $(0.281)$ & $(0.252)$ & $(0.224)$ & $(0.205)$ & $(0.188)$ & $(0.220)$ \\
& 0.414 & 0.061 & 0.082 & -0.166 & 0.245 & 0.059 \\
Public admin. & $(0.296)$ & $(0.269)$ & $(0.234)$ & $(0.223)$ & $(0.201)$ & $(0.228)$ \\
Healthcare & -0.250 & -0.004 & 0.226 & 0.282 & 0.050 & 0.112 \\
Education & $(0.214)$ & $(0.218)$ & $(0.205)$ & $(0.212)$ & $(0.194)$ & $(0.200)$ \\
Constant & -0.456 & -0.149 & 0.279 & 0.312 & -0.162 & 0.072 \\
Observations & $(0.300)$ & $(0.327)$ & $(0.272)$ & $(0.279)$ & $(0.269)$ & $(0.277)$ \\
& 0.021 & 0.215 & 0.289 & 0.129 & -0.113 & 0.285 \\
& $(0.200)$ & $(0.196)$ & $(0.177)$ & $(0.184)$ & $(0.184)$ & $(0.206)$ \\
& $2.401^{* * * *}$ & $2.185^{* * *}$ & $1.966^{* * *}$ & $2.596^{* * *}$ & $2.797^{* * * *}$ & $2.678^{* * * *}$ \\
& $(0.310)$ & $(0.315)$ & $(0.304)$ & $(0.310)$ & $(0.281)$ & $(0.331)$ \\
& 263 & 265 & 269 & 274 & 250 & 261 \\
& 0.057 & 0.076 & 0.075 & 0.048 & 0.065 & 0.075 \\
\hline & & & & $* \mathrm{p}<0.1 ;^{* *} \mathrm{p}<0.05 ;^{* * *} \mathrm{p}<0.01$
\end{tabular}

Note. The table shows estimates of treatment effect in regression setting. Dependent variable is the number of chosen items of the sensitive question in either the control or a treatment group. Columns 1-3 (4-6) estimate average treatment effects for treatments 1-3 respectively with breakdown by gender for low-ranked (highranked) workers. 
Table A7. Upper bound for average treatment effect with breakdown by gender and position

\begin{tabular}{lcccccc}
$\begin{array}{l}\text { Position } \\
\text { Gender }\end{array}$ & \multicolumn{3}{c}{ Female } & & \multicolumn{3}{c}{ Male } \\
\hline High- & Treatment 1 & Treatment 2 & Treatment 3 & Treatment 1 & Treatment 2 & Treatment 3 \\
ranked & 0.402 & 0.409 & 0.771 & 0.252 & 0.16 & 0.58 \\
& $(0.009)$ & $(0.01)$ & $(<0.001)$ & $(0.171)$ & $(0.268)$ & $(0.019)$ \\
\hline \multirow{2}{*}{ Low- } & Treatment 1 & Treatment 2 & Treatment 3 & Treatment 1 & Treatment 2 & Treatment 3 \\
ranked & 0.483 & 0.614 & 0.636 & 0.568 & 0.5 & 0 \\
& $(0.003)$ & $(<0.001)$ & $(<0.001)$ & $(0.025)$ & $(0.038)$ & $(0.5)$ \\
\hline
\end{tabular}

Note. To see if ceiling effect could have affected the results, we use the following approach: replace all answers 4 in treatment groups with 5 . The estimates after the change suggests the results that would be if all respondents are vulnerable to ceiling effect. This approach yields the upper bound for true attitude to corruption. The table shows the differences between corresponding treatment group and the control group with breakdown by position and gender. P-values in parentheses are for a one-sided t-test for comparison with the corresponding control groups (the alternative hypothesis is that the mean in a treatment group is larger than the mean in the control group). The differences can be interpreted as the proportions of the bureaucrats distinguishing the corresponding corrupt aspect within a position-gender group. 